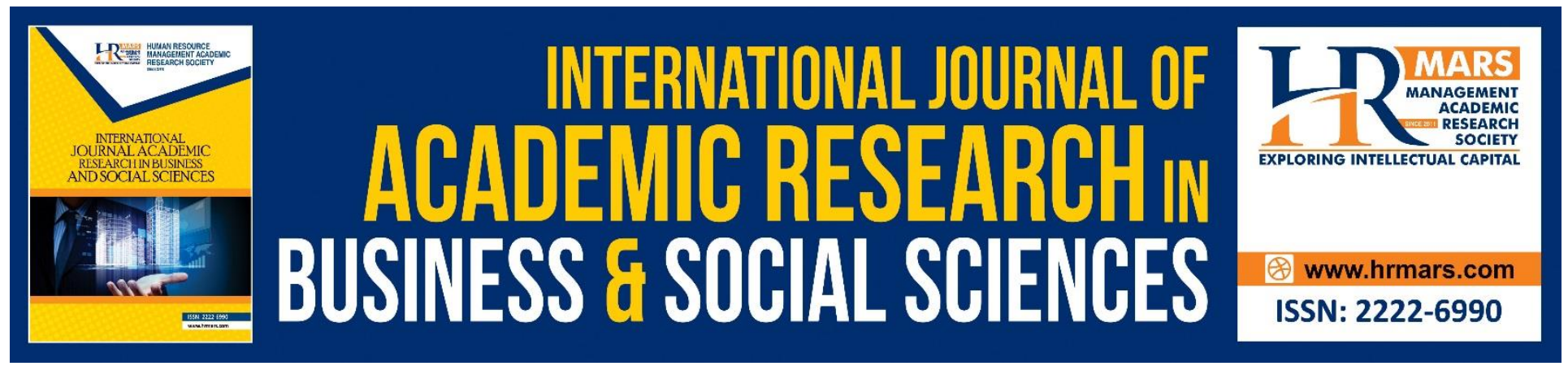

\title{
Proficiency of Javanese Language in Developing Identity Among Javanese Youth
}

Mohd Hasrul Yushairi B. Johari, Zamzuri Ahmad Nazari

To Link this Article: http://dx.doi.org/10.6007/IJARBSS/v9-i1/5511 DOI: $10.6007 /$ IJARBSS/v9-i1/5511

Received: 11 Dec 2018, Revised: 09 Jan 2019, Accepted: 21 Jan 2019

Published Online: 28 Jan 2019

In-Text Citation: (Johari \& Nazari, 2019)

To Cite this Article: Johari, M. H. Y. B., \& Nazari, Z. A. (2019). Proficiency of Javanese Language in Developing Identity Among Javanese Youth. International Journal of Academic Research in Business and Social Sciences, 9(1), 1088-1098.

Copyright: @ 2019 The Author(s)

Published by Human Resource Management Academic Research Society (www.hrmars.com)

This article is published under the Creative Commons Attribution (CC BY 4.0) license. Anyone may reproduce, distribute, translate and create derivative works of this article (for both commercial and non-commercial purposes), subject to full attribution to the original publication and authors. The full terms of this license may be seen at: http://creativecommons.org/licences/by/4.0/legalcode

\section{Vol. 9, No. 1, 2019, Pg. 1088 - 1098}




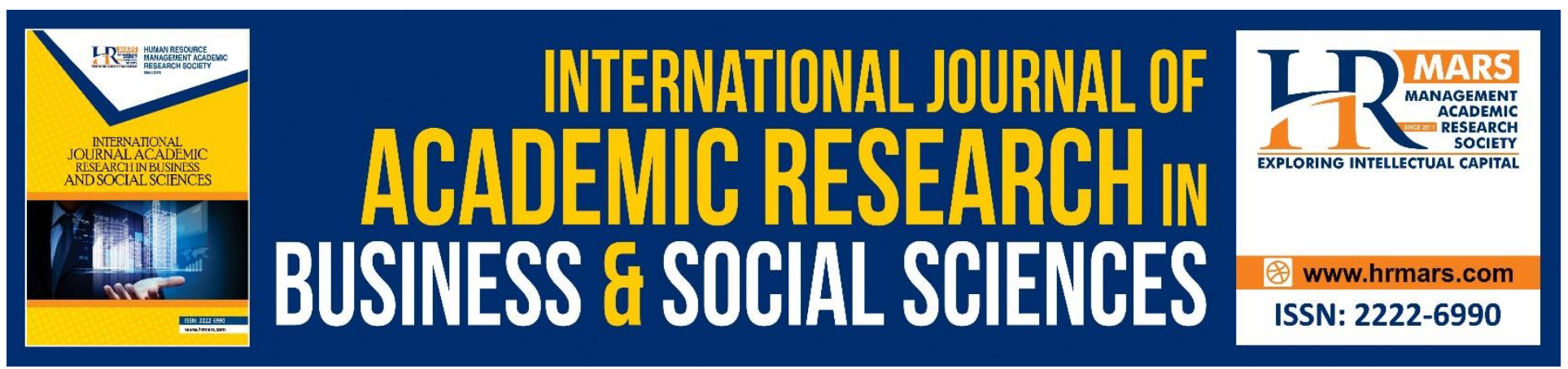

\title{
Proficiency of Javanese Language in Developing Identity Among Javanese Youth
}

\author{
Mohd Hasrul Yushairi b. Johari, Zamzuri Ahmad Nazari \\ Universiti Teknologi MARA, Kampus Bandaraya Melaka, Malaysia \\ Email: hasrul436@uitm.edu.my
}

\section{Abstract}

Javanese ethnic has unique tradition and identity in terms of character, social class, culture, food and language. Generally, Javanese youth in Malaysia are raised speaking in their native tongue interchangeably with modern Malay language. When they enter school, they become fluent in modern Malay language as a second language, hence seldom use their native Javanese language. Unfortunately, the Java language is less practiced among young Javanese. Most of them have neither learned it nor capable how to speak in their native language. Currently, it seems that young Javanese incompetent in their own Javanese language. Social lifestyle and surrounding environment are believed to influence the likeliness of young Javanese to communicate in this language. This study was conducted to assess the proficiency of Java language among its young adult, aged between 18 and 26 years old. About 384 questionnaires were distributed to respondents who live in Batu Pahat, Johor. It was revealed that most Javanese youth were not able to speak in their native language. This research was deemed important to explore whether the language is preserved by its own ethnic.

Keywords: Heritage language, Native language, Identity, Language fluency, Ethnic language

\section{Introduction}

The Javanese is one of the sub ethnics in Malay who have contributed to a more multicultural community in Malaysia. Javanese migrants were believed to become pioneer settlers in west coast of Malaya (former name of Malaysia before 1963) and most of them migrated from Central Java, Indonesia to Malaya around 1880 to 1930. The main driving factor of these migrations was mostly due to hardship created by the Dutch colonial regime and the dense population of the Java Island itself. Today, the Javanese descendants could be identified throughout Peninsular Malaysia especially in Perak, Selangor, Johor and Kedah. In Malaysia, it is estimated the total numbers of Javanese population are around 640,000. Javanese ethnic has unique tradition and identity in terms of character, culture, food and language (Sheikh, 2012). Nowadays, the Javanese population has grown thus, becomes dominant settler in the State of Johor. Most of the Javanese presently attain high education and are holding important positions in the public sector in Johor and the Federal 
government (Sheikh, 2012). Unfortunately, despite this progress, Javanese language has never been placed as priority among its young generations. Stemming from this imperfection, this study ought to determine whether the young generation able to communicate in Java language as well as to investigate whether Java language is not important as perceived by young generation.

It is also relevant to note that the value of ethic is highly welcomed in Javanese culture. Politeness is extremely observed, and adherent is a must. It is very important for one to conform to this and the Javanese has a specific term for this which is called "Ngajeni" which means full respect. Other specific ethical principle strongly held by Javanese is "Narimoingpandum" which means full acceptance to what you have. These characters signify the life principle to the total submission to whatever God has given them (Widodo \& Saddhono, 2012).

In general, the use of native language at home could maintain the continual use of traditional language. However, the Javanese language receives little attention by its young adult group because they think that their mother tongue dialect is outdated. The proficiency skills diminished steadily when the community is exposed to different kinds of other lingo when they migrate to other places. Javanese language is no longer taught to young generation in their daily communication, therefore there is an issue on its sustainability in maintaining the language for daily conversation (Kim \& Chao, 2009). Kim and Chao (2009) identify even though the parents are good Javanese speakers, they sometimes put priority to speak in Bahasa Melayu or Malay language with their children. Perhaps, this is due to some of the Javanese vocabularies are no longer used because it has lost its function in modern conversation which are replaced by modern Malay words (Dwi, 2013). Malone and Malone (2011) also identify the limited understanding of knowing their own language is the drawback to sustain the continuation of mother tongue in daily communication. In addition, in Malaysia ethnic language is not receiving any emphasis in formal education. Language is found to be the most important tool in communication, as language decodes message being conveyed by others. Therefore, communication requires an understanding and recognition of the people who uses it (Griffiths \& Oxford, 2014). These acts require knowledge of the language, as well as the cultural and social forces attached to that language. The Javanese community in Malaysia speaks Javanese and Malay interchangeably. It is ironic when young Javanese community in Malaysia does not practice their own mother tongue daily, hence resulting to incompetency. Therefore, several research questions guided the study. First, is heritage language a salient aspect of participants' cultural identities? and second, if so, in what way(s) does this language familiarity considered as relevant? Pawitand and Sheikh Said (2014) discover that young adult in the category of 16 to 18 years old are the least to speak in Javanese language. The use of the language is also low between age 19 and 25 years, especially those studying in higher education institutions and who are working since they view that Javanese language is old-fashioned and outdated since it is assumed as rural language, thus perceived as not professional and universal (Sudarmawan, 2005).

The above arguments outlined a significant proposition to be tested as in the following hypotheses:

$\mathrm{H}_{1}$ : There is a strong relationship between language attitude and Javanese identity. 
The first hypothesis was proposed because language contributes to construct identity of the respondents. It was proposed to investigate whether attitude to use the language shaped respondents' identity of becoming a pure Javanese. The proposition assessed whether ability to demonstrate positive language attitude influenced a higher sense of pride of being a Javanese vice versa.

$\mathrm{H}_{2}$ : Javanese language fluency influences the identity of the ethnic.

This hypothesis was to identify whether the language fluency portrays the identity of an ethnic. Fluency is regarded an opportunity for an ethnic to show their proud in front of others. It explains about the uniqueness of their identity which is so special that other ethnic does not have. Eloquence in language portrays an identity of an ethnic indicating that a person thinks it is a must for him/her to sustain the language as intangible heritage.

\section{Methodology}

In the view of the concentration of Javanese descendants (Sheikh, 2012), this study has selected the city of Batu Pahat which itself has a population of more than 300,000. There are more than 100,000 households with 468,058 populations in this district. The most populated mukim is Simpang Kanan with more than 250,000 people and the least populated is Bagan with a population of only 4,692. Based on gender distribution, both male and female are almost equal with a male population of 169,087 and female population of 166,281 . Batu Pahat city is made up of $37.08 \%$ Bumiputera (mainly Malay), 60.29\% Chinese and $2.54 \%$ Indian and other ethnic.

This research utilized random sampling by targeting only young adults who live in the area. For this study, the most appropriate method of administrating the survey was through intercept interview, a face-to-face communication that targets respondents in a centralized location (Kerstetter, Confer \& Graefe, 2001). Most respondents were easily identified at town, streets, schools, shops and the banks. They were randomly selected at those areas and were asked to complete a questionnaire. Almost 384 questionnaires were distributed to respondents with Javanese background. Respondents were selected from those who admit as a Javanese by using the dichotomous question of 'Yes' and 'No'. If the answer is 'No', no further questions were directed to respondents and vice versa if the answer was 'Yes'. In addition, if a 'No' answer was revealed, the respondents were dropped as sample. Respondents were approached at the above mentioned city and informed about the purpose of the survey before they were given the questionnaire.

\section{Survey Instrument}

The questionnaire in the study was designed in dual language which was in English and Malay. The questionnaire consisted of three sections. First section contained demographic question such as gender, age, marital status, educational level and what language they usually speak at home. Second section consisted of 11 questions that probed into respondent's attitude and identity towards Javanese language. Respondents were requested to give scale to each of the 11 attributes using a 5- 
point Likert scale which ranged from 'highly disagree' (1) to 'highly agree' (5) respectively. The last section covered four questions on the language fluency such as how well they understand the Javanese language when communicating, how well is their command of Javanese language, how well they can read and write the Javanese language, and lastly how well are their parents' proficiency in Javanese language at home. Respondents were asked to rate their fluency using 5-point Likert scale which ranged 'not fluent at all' (1) to 'extremely fluent' (5). Questionnaires were tested for content validity (reliability coefficient), determined by Cronbach's alpha that produced .748. In this study, 384 questionnaires were administered but only 343 were found suitable for the data analysis.

\section{Results of the Study}

The findings revealed there were more female (56.6\%) than male respondents (43.4\%). Among them, majority were individuals between $21-23$ years old (49.3\%) followed by respondents aged between 24-26 years old at $27.4 \%$ and $27-29$ years old at $13.7 \%$. Only $9.6 \%$ respondents aged between $18-20$ years old. Among the respondents, majority $80.5 \%$ were single, $17.8 \%$ married and only $1.7 \%$ were divorced. In terms of educational level, majority of the respondents were undergraduate (67.6\%), followed by primary and secondary schools at $22.7 \%$. Meanwhile, $8.5 \%$ for other level of education and only $1.2 \%$ for post-graduate. For other level of education, most were at their foundation studies and diploma. Next, regarding to the Javanese status, majority $(100 \%)$ of the respondents were Javanese. Furthermore, with regards to the daily language used at home majority used the national language, i.e. Malay language (73.5\%). Followed by practiced Javanese language (25.4\%) and the least was English (1.2\%).

\section{Language Attitude}

Overall, language attitude means were above the scale of 3.00. From the analysis, it was revealed that majority of respondents did not use Java language for primary communication in their daily life at home (mean2.59, last rank). It was also found that Javanese language was not useful in studying (mean=4.14), followed by the respondents need to improve their mother tongue (mean=3.99). It was interesting to learn when respondents felt annoyed when someone belittle with their native language (mean=3.81), signify that these young adults seemed to have a sense of belonging of their identity. In addition, it also illustrated that the respondents did not deny their linguistic rootedness. The respondents agreed that Javanese language was not useful in their study since the language was not used at school. As the Javanese language is not useful in studying, they tend to leave Java language as they thought it was not the factor to shape their identity. Although the respondents showed deep interest in learning Javanese language (ranked fourth), at the same time it was a hurdle when the language was difficult to learn (rank fifth). It is also relevant to note that respondents found difficulty in reading and writing Javanese language because most of them were exposed to an environment outside of their communities for working and studying which did not require the usage of the language. This demonstrate that parents' role is important to teach their children practicing the Javanese language at home. In this way, the use of Javanese language is continued and preserved. 
INTERNATIONAL JOURNAL OF ACADEMIC RESEARCH IN BUSINESS AND SOCIAL SCIENCES

Vol. 9, No. 1, Jan, 2019, E-ISSN: 2222-6990 (C) 2019 HRMARS

Table 1.0

Language attitude

\begin{tabular}{|c|c|c|c|c|c|c|c|c|c|}
\hline & Language Attitude & 1 & 2 & 3 & 4 & 5 & Mean & Std Dev & Rank \\
\hline 1 & $\begin{array}{l}\text { I frequently } \\
\text { communicate in Java } \\
\text { with my friend or } \\
\text { family. }\end{array}$ & 67 & 137 & 31 & 85 & 23 & 2.59 & 1.239 & 9 \\
\hline 2 & $\begin{array}{l}\text { Java language is a } \\
\text { difficult to learn. }\end{array}$ & 19 & 90 & 35 & 159 & 40 & 3.32 & 1.146 & 5 \\
\hline 3 & $\begin{array}{l}\text { I show a deep } \\
\text { interest to learn } \\
\text { Java language. }\end{array}$ & 6 & 74 & 22 & 198 & 43 & 3.58 & 1.017 & 4 \\
\hline 4 & $\begin{array}{l}\text { I feel lack of } \\
\text { confident when } \\
\text { speaking Java } \\
\text { language. }\end{array}$ & 33 & 109 & 31 & 132 & 38 & 3.10 & 1.235 & 8 \\
\hline 5 & $\begin{array}{l}\text { I need to improve } \\
\text { my Java language. }\end{array}$ & 4 & 45 & 29 & 136 & 128 & 3.99 & 1.046 & 2 \\
\hline 6 & $\begin{array}{l}\text { Java language seems } \\
\text { not to be useful in } \\
\text { my studying. }\end{array}$ & 10 & 16 & 29 & 150 & 138 & 4.14 & 0.959 & 1 \\
\hline 7 & $\begin{array}{l}\text { My family } \\
\text { encourages me to } \\
\text { speak Java language. }\end{array}$ & 42 & 96 & 26 & 132 & 46 & 3.13 & 1.298 & 7 \\
\hline 8 & $\begin{array}{l}\text { Practicing my } \\
\text { mother tongue } \\
\text { make me close to } \\
\text { self-identity. }\end{array}$ & 19 & 90 & 85 & 117 & 32 & 3.15 & 1.085 & 6 \\
\hline \multirow[t]{2}{*}{9} & $\begin{array}{l}\text { I feel annoyed when } \\
\text { someone belittle my } \\
\text { native language. }\end{array}$ & 4 & 50 & 44 & 154 & 91 & 3.81 & 1.024 & 3 \\
\hline & Language Identity & & & & & & & & \\
\hline 1 & $\begin{array}{l}\text { Overall, I feel proud } \\
\text { of my Javanese } \\
\text { identity when I } \\
\text { speak Java. }\end{array}$ & 6 & 57 & 35 & 174 & 71 & 3.72 & 1.028 & \\
\hline
\end{tabular}

\section{Language fluency}

The overall means for language fluency was slightly above 2.00 signified that respondents did not competent in speaking in their own mother tongue language. It seems that from Table 2.0 majority did not have a good command of the language. They did not understand when others speak in the native language, hence unable to respond. It was discovered that young Javanese were somewhat understand their parents who communicate with each other in Java, but they have difficulty to respond in the same language. For this reason, perhaps parents could create a culture at home where every member in the family speak Java to improve fluency in the language (see Table 2.0). 
INTERNATIONAL JOURNAL OF ACADEMIC RESEARCH IN BUSINESS AND SOCIAL SCIENCES Vol. 9, No. 1, Jan, 2019, E-ISSN: 2222-6990 (C) 2019 HRMARS

Table 2.0

Language fluency

\begin{tabular}{|c|c|c|c|c|c|c|c|c|}
\hline & Language Fluency & 1 & 2 & 3 & 4 & 5 & Mean & $\begin{array}{l}\text { Std. } \\
\text { Dev }\end{array}$ \\
\hline 1 & $\begin{array}{l}\text { How well do you } \\
\text { understand Java } \\
\text { language when } \\
\text { others } \\
\text { communicate } \\
\text { with you? }\end{array}$ & 81 & 130 & 26 & 78 & 28 & 2.54 & 1.292 \\
\hline 2 & $\begin{array}{l}\text { How well do you } \\
\text { have a good } \\
\text { command of Java } \\
\text { language? }\end{array}$ & 167 & 67 & 33 & 60 & 16 & 2.10 & 1.303 \\
\hline 3 & $\begin{array}{l}\text { How well do you } \\
\text { read and write the } \\
\text { Java language? }\end{array}$ & 253 & 42 & 19 & 20 & 9 & 1.51 & 1.014 \\
\hline
\end{tabular}

\section{Hypotheses Testing}

Table 3.0

Pearson correlation between language attitude and identity

\begin{tabular}{clc}
\hline & Language Attitude & $\begin{array}{c}\text { Javanese } \\
\text { identity }\end{array}$ \\
\hline 1 & $\begin{array}{l}\text { Frequent } \\
\text { communication }\end{array}$ & $0.464(0.000)^{* *}$ \\
2 & Learning difficulty & -0.270 \\
3 & Learning interest & $0.555(0.000)^{* *}$ \\
4 & Lack of confident & -0.225 \\
& & $(0.000)^{* *}$ \\
5 & Need to improve & $0.485(0.000)^{* *}$ \\
6 & Not useful in studying & $0.000(0.993)^{\text {n.s. }}$ \\
7 & Family encouragement & $0.505(0.000)^{* *}$ \\
8 & Close to identity & $0.492(0.000)^{* *}$ \\
9 & Annoyed when someone & $0.602(0.000)^{* *}$ \\
& belittle & \\
\hline
\end{tabular}

*** Correlation is significant at the 0.01 level (1-tailed).

Based on Table 3.0, hypothesis $\mathrm{H}_{1}$ was accepted but excluding element 'not useful in studying' that registered insignificant at $\mathrm{P}<0.01$. This data clarified that even though the language was not used in tertiary education, that did not mean it deteriorates the root identity of the respondents. For 
example, from the table, it was found that youngsters were determined to improve their native language skills $(P<0.000)$. However, the passion for language improvement is highly dependent on the attitude of how strongly they want to safeguard the Javanese language and how proud they are with their identity when they speak Javanese. These portray some great challenges since majority of these Javanese young adults were having lack of confident when speaking in their heritage language, thus impede their identity as well $(P<0.000)$ (see Table 4.0).

Table 4.0

Pearson correlation between language fluency and identity

\begin{tabular}{|c|c|c|}
\hline Language fluency & & $\begin{array}{l}\text { Ethnic } \\
\text { identity }\end{array}$ \\
\hline \multirow{3}{*}{$\begin{array}{l}\text { Able to understand } \\
\text { language }\end{array}$} & Pearson & .484 \\
\hline & Correlation & \\
\hline & Sig. (1-tailed) & $.000 * *$ \\
\hline \multirow{3}{*}{$\begin{array}{l}\text { Good command of } \\
\text { language }\end{array}$} & Pearson & .231 \\
\hline & Correlation & \\
\hline & Sig. (1-tailed) & $.000 * *$ \\
\hline \multirow{3}{*}{$\begin{array}{l}\text { Fluency in writing \& } \\
\text { reading Java }\end{array}$} & Pearson & .231 \\
\hline & Correlation & \\
\hline & Sig. (1-tailed) & $.000 * *$ \\
\hline
\end{tabular}

**Correlation is significant at the 0.01 level (1-tailed).

Based on Table 4.0, hypothesis 2 was accepted that all salient aspect of language fluency significantly related to identity. According to Owen (2011), by means of language identity, individuals put values to the community who speak the inherited language since it is their traditional practice since the time of forefathers that finally become a distinctive identity. In this case, young adult Javanese moderately understands their heritage language when their parents communicate with others but still they have a problem responding in such dialect. Even though most of their elders speak Javanese daily, but it seems that literacy in the home language was not given priority, especially among youngsters. In general, nowadays, the growing acceptance of home-language maintenance was gradually tolerated with the mastery of majority language, i.e. Bahasa Melayu moden (modern Malay language). The wide usage of the Malay language in education meant that the value of Javanese language has been deemed not valuable by young generation which is a threat to this intangible cultural heritage. In view of this, parental encouragement of cultural maintenance and native language interactions were needed to improve fluency, thus influence ethnic identity (Phinney, Romero, Nava and Huang, 2011). Eisenchlas, Shcalley, Guillemin (2013) emphasize that home-language literacy programs are desirable to improve literacy of home-language speakers. However, lack of support for home languages which are defeated to widely diverse use of other commercial language poses great practical challenges in the implementation of such programs. The authors identify lack of trained teachers in native languages and scarcity of heritage language references contribute to the incapable of native language eloquence. 


\section{Discussion}

Nowadays, many young adults are more likely a product of mixed marriage. As a result, there is a problem in determining the principal mother tongue because of mixed family background. Children of mixed marriage will have two or more ancestral languages. This has led to the possibility that two kind of languages are used at home. For example, Javanese family members who communicate in native Java and Malay face a problem between frequent and infrequent use of language. If one language dominates the other, then the less spoken language becomes the victim of ignorance. Moreover, the native language might not be the popular language of the children since they are exposed to national language which is widely spoken outside of their home and that same national language is also formally used at schools and institution of higher learning. Perhaps, the ability to speak in this native language is not considered to be special or having the privilege in the society even though the number of native speakers among the elders is relatively high. After all, there is no pressure from any agencies or bodies to uplift the usage of this traditional heritage language.

In view of instilling pride in Javanese heritage, Javanese youth could probably have a good command of the Javanese language itself. Thus, by referring to the Cognitive Evaluation Theory put forward by Ryan and Deci (2000) has identified that inhibiting intrinsic motivation in an individual as a form of reward has to be evident as a catalyst for enhancing motivation. As in the case of the Javanese language proficiency, the promotion of the value of Javanese heritage as a source of pride could be the form of reward that is needed in developing intrinsic motivation of being proud of their heritage. A study (Bannon, McKay, Chacko, Rodriguez \& Cavaleri (2009) on cultural pride itself shows that parents who impart cultural pride as part of their parenting has shown that their children had lower anxiety in identifying themselves as belonging to a certain culture. Positive reinforcement by parents on endorsing the cultural heritage through language and history among others will inculcate a positive view of their cultural identity thus creating pride for younger generation to project their culture to society without the feeling of potentially being alienated. In this regard, parents should play a role in developing their children's ability in mastering native language at home by encouraging them to speak in mother tongue. Furthermore, Javanese youngsters might perhaps participate in cultural Javanese ceremony where they can mingle with the older generation thus enhancing their Javanese language skills by communicating with speakers who mastered the language. The probability of new vocabulary and phonetics enrichment could happen in such setting. Other than that, such events would help young generation to connect with their Javanese roots and creates a sense of pride in their identity. There should be efforts to ensure continuity and survival of the Javanese language. However, it must be supported by the community itself to execute plans to deliver quality basic education in Javanese language. Even though this native language is competing with the widely spoken national language, it is hoped that through systematic approach, learning and teaching could elevate the level of proficiency among young adult speakers.

\section{References}

Bannon, J.W., McKay, M., Chacko, A., Rodriguez, J., \& Cavaleri, M. (2009). Cultural pride reinforcement as a dimension of racial socialization protective of urban African American child anxiety. Families in Society: The Journal of Contemporary Social Services, 90(1), 79-86. 
INTERNATIONAL JOURNAL OF ACADEMIC RESEARCH IN BUSINESS AND SOCIAL SCIENCES

Vol. 9, No. 1, Jan, 2019, E-ISSN: 2222-6990 (C) 2019 HRMARS

Cohn, A. \& Ravindranath, M. (2014). Local language in Indonesia: Language maintenance or language shift? Linguistik Indonesia, 32 (2), 131-148.

Dwi, W. (2013). The importance of positive language attitude in maintaining Javanese language. Proceedings from International Seminar of Language Maintenance and Shift II, July 2 - 3, 2013. Semarang.

Eisenchlas, S. A. , Schalley, A. C. , \& Guillemin, D. (2013). The Importance of literacy in the home language: The view from Australia. Sage Open. October-December 2013 pp 1-14. https://doi.org/10.1177/2158244013507270

Griffiths, C. \& Oxford, R. (2014). Twenty-first century landscape of language learning strategies. System, 43, 1-10. http://doi 101016/j.system.2013.12.009

Kerstetter, D. L., Confer, J. J., \& Graefe, A. R. (2001). An exploration of the specialization concept within the context of heritage tourism. Journal of Travel Research, 39, 267-274.

Kim, S. Y., \& Chao, R. K. (2009). Heritage language fluency, ethnic identity, and school effort of immigrant Chinese and Mexico adolescents. Cultural diversity \& ethnic minority psychology, 15(1), 27-37.

Malone, D. \& Malone S. (2011). Teacher education for mother tongue1based education programs. Retrieved from https://www.sil.org/sites/default/files/files/institutionalizing teacher training for mtb mle 12-2011.pdf

Owen, C. (2011). Language and cultural identity: Perceptions of the role of language in the construction of Aboriginal identities (Master dissertation). Carleton University, Ottawa, Ontario.

Pawitand, M. F. \& Sheikh Said, N. (2014). Pengaruh Bahasa Jawa dalam pembauran kod golongan muda Melayu berketurunan Jawa. Jurnal Antarabangsa Alam dan Tamadun Melayu (Iman), 2, 77-85.

Phinney, J., Romero, I., Nava, M. (2001). The Role of Language, Parents and Peers in Ethnic Identity Among Adolescents in Immigrant Families. Journal of Youth and Adolescence, 30 (2), 135-153.

Ryan, R. M., \& Deci, E. L. (2000). Self-determination theory and the facilitation of intrinsic motivation, social development, and well-being. American psychologist, 55(1), 68.

Sheikh Said, N. (2012). Sejarah kedatangan orang Jawa ke Johor. Retrieved from http://sejarahtunsheikh.blogspot.com/2012. 
INTERNATIONAL JOURNAL OF ACADEMIC RESEARCH IN BUSINESS AND SOCIAL SCIENCES

Vol. 9, No. 1, Jan, 2019, E-ISSN: 2222-6990 @ 2019 HRMARS

Sudarmawan, H. (2005). Tingkat tutur bahasa Jawa krama pada generasi muda sinoman di Kecamatan Grogol Kabupaten Sukoharjo (Master dissertation). Universitas Sebelas Maret, Surakarta.

Widodo, S. T. and Saddhono, K. (2012) Petangan tradition in Javanese personal naming practice: An ethnoliguistic study. GEMA: Online Journal of Language Studies, 12 (4), 1165-1177. ISSN 16758021. 